Biota Vol. 15 (1): 58-62, Februari 2010

ISSN 0853-8670

\title{
Karakterisasi Kromosom Sel Heterohibrida Dengan Teknik Karyotiping
}

\author{
Characterisation of the Heterohybride Cells Chromosome by Karyotyping Technique
}

\section{Ketut Berata}

Lab. Patologi, Fakultas Kedokteran Hewan Universitas Udayana, Jl Tukad Banyu Poh VII No.21 Denpasar Bali

E-mail : iketutberata@yahoo.com

\begin{abstract}
The aim of the research was to characterize the chromosomal structure of the heterohybride cells by karyotyping technique. Heterohybride cells were made by fusion of Bali cattle lymphocyte cells with mouse myelomma in selective medium which contains hypoxanthin, aminopterin and thymidine. Those cells which showed growth then were identified, selected and isolated for characterizing its chromosomal structure by karyotyping technique. The result showed that all of the chromosomal structure of the heterohybride cells were diploidy. The average of diploidy chromosome of heterohybride cells were 97 diploid Bali cattle lymphocyte cells and myelomma of mouse. The conclusion of the research is the heterohybride cells do not contain abnormal chromosome and are most potent to develop as candidate of Jembrana diseases vaccine.
\end{abstract}

Key words: Heterohybride cells, characterized, karyotyping

\begin{abstract}
Abstrak
Tujuan dari penelitian ini adalah mengkarakterisasi struktur kromosom sel-sel heterohibrida dengan teknik karyotiping. Sel-sel heterohibrida dibuat dengan cara memfusikan sel-sel limfosit dengan myeloma mencit dalam media selektif yang mengandung hypoxanthin, aminopterin dan thymidin. Sel-sel yang menunjukkan pertumbuhan diidentifikasi, diseleksi dan diisolasi untuk karakterisasi struktur kromosomnya dengan teknik karyotiping. Hasil penelitian menunjukkan bahwa semua struktur kromosom sel-sel heterohibrida bersifat diploid. Rata-rata diploid kromosom sel-sel heterohibrida adalah 97 diploid sel-sel limfosit dan myeloma mencit. Kesimpulan dari penelitian adalah sel-sel heterohibrida tidak mengandung kromosom abnormal dan potensial dikembangkan sebagai kandidat vaksin penyakit Jembrana.
\end{abstract}

Kata kunci: Sel-sel heterohibrida, karakterisasi, karyotiping

Diterima: 12 Maret 2009, disetujui: 13 Januari 2010

\section{Pendahuluan}

Sel heterohibrida adalah sel hasil fusi limfosit sapi Bali dan sel mieloma mencit yang dibuat dengan teknik kultur. Sel heterohibrida dibuat untuk memperoleh limfosit yang memiliki sifat limfosit sapi Bali dan dapat dibuat dalam jumlah banyak, karena sifat sel mieloma. Sel heterohibrida ini diharapkan dapat menggantikan limfosit sapi Bali sebagai tempat pembiakan virus penyakit Jembrana pada sapi Bali. Dalam hasil penelitian dilaporkan bahwa virus penyakit Jembrana sulit tumbuh dalam kultur kecuali dalam limfosit sapi Bali (Kertayadnya et al., 1993). Sel heterohibrida pertama kali dibuat dan berhasil diinfeksi dengan virus penyakit
Jembrana dilaporkan oleh Astawa et al., (2005). Sel heterohibrida yang terinfeksi virus penyakit Jembrana merupakan sumber antigen untuk pembuatan vaksin kultur terhadap penyakit Jembrana, sebagai alternatif vaksin saat ini yang disebut vaksin limpa.

Vaksin limpa dibuat dari limpa sapi Bali yang diinokulasi dengan virus penyakit Jembrana (Hartaningsih et al., 2001). Pengambilan limpa untuk mengisolasi antigen virus penyakit Jembrana, dengan jalan membunuh sapi donor. Langkah membunuh sapi donor ini merupakan kelemahan teknik pembuatan vaksin limpa. Oleh karena itu, alternatif pembuatan vaksin kultur yang dibuat dari antigen virus penyakit Jembrana pada sel heterohibrida sangat potensial untuk 
dikembangkan. Hasil penelitian uji respons kekebalan seluler dengan pemberian vaksin kultur hasilnya lebih tinggi dari pada pemberian vaksin limpa yang dilakukan pada hewan coba mencit BALB/c (Berata dan Astawa, 2007). Hal ini menunjukkan bahwa vaksin kultur, termasuk kultur sel heterohibrida di masa mendatang memiliki potensi besar untuk dikembangkan.

Sebelum antigen virus penyakit Jembrana darikultur sel heterohibrida diaplikasikan sebagai bahan vaksin kultur, maka berbagai penelitian harus dilakukan. Syarat sebagai vaksin selain memiliki daya proteksi yang tinggi juga harus aman dari efek samping vaksin tersebut. Dalam hal sel heterohibrida, sifat mieloma sel heterohibrida dikhawatirkan masih memiliki sifat karsinogen. Karakteristik sel heterohibrida perlu diteliti terhadap kemungkinan adanya sifat karsinogen tersebut. Salah satu karakteristik sel bersifat karsinogen adalah berdasarkan adanya ab-noralitas kromosomnya. Untuk meneliti karakteristik kromosom dapat dilakukan karyotiping. Sel kanker memiliki kromosom yang poliploid atau aneuploid dan struktur kromosom yang tidak stabil (Camps et al., 2005; Fabarius et al., 2003). Bagaimana struktur dan jumlah pasang (2n) kromosom sel heterohibrida hasil karakterisasi dengan teknik karyotiping, perlu dilakukan penelitian.

Tujuan penulisan ini adalah memberikan sumbangan pengetahuan tentang karyotipe sel heterohibrida yang merupakan hasil fusi sel limfosit sapi Bali dengan sel mieloma mencit, yang dilakukan dengan teknik karyotiping.

\section{Metode Penelitian}

\section{Bahan dan Alat Penelitian}

Bahan dalam penelitian adalah limfosit sapi Bali, mieloma mencit, media RPMI-140, media DMEM, media selektif DMEM yang mengandung hipoxantin, aminopterin dan thymidin (HAT), fetal calf serum (FCS) 10\%, Polyethylene glycol (PEG), colcemid (Sigma), EDTA 5\%, picoll-paque (Sigma), PBS steril (pH 7,22-7,4). Antibiotika, sodium piruvat, glutamin, acetic metanol, tripsin. Alat-alat yang digunakan adalah tabung steril $20 \mathrm{ml}$, spuite $8 \mathrm{G}$, pipet transfer, alat sentrifugasi, flask, mikroplat, vortex, gelas objek, inkubator dan mikroskop cahaya.

\section{Desain Penelitian}

Uji karyotiping dilakukan pada sel heterohibrida serta sel mieloma dan limfosit sapi Bali sebagai komponen pembuatan sel heterohibrida. Tiap-tiap sel dilakukan pengulangan sebanyak 10 kali. Sebagai gambaran umum sel yang dilakukan karyotiping (Gambar 1), menggambarkan sel heterohibrida dibuat dengan memfusikan sel limfosit sapi Bali dan mieloma mencit. Tiap-tiap sel dilakukan kultur sebanyak 10 kali dan di karyotiping sebanyak 10 kali pula.

\section{Parameter}

Parameter yang diukur pada penelitian: Keadaan diploid (2n) sel heterohibrida, sel mieloma dan limfosit sapi Bali serta jumlah pasang (2n) dari sel heterohibrida, sel mieloma dan limfosit sapi Bali.

\section{Analisis Data}

Data hasil pengamatan dan penghitungan diploid atau jumlah pasangan kromosom dianalisis secara deskriptif.

\section{Tahapan Cara Kerja}

\section{Isolasi Limfosit Sapi Bali}

Sapi Bali yang sehat diadaptasikan selama 2 minggu dengan pemberian makan rumput gajah dan minum ad libitum. Pada minggu pertama adaptasi, vaksin terhadap penyakit SE (septicemia epizootica) disuntikkan dan diberi obat cacing, agar diperoleh darah bebas penyakit. Setelah masa adaptasi, darah dari vena jugularis diambil sebanyak $20 \mathrm{ml}$ dan ditampung pada tabung yang telah diisi antikoagulan EDTA. Darah disentrifugasi $12.000 \mathrm{rpm}$ selama 30 menit. Dengan pipet transfer, buffy coat diambil dan dimasukkan ke tabung yang telah diisi picoll-paque. Tabung dengan isi picollpaque dan buffy coat disentrifugasi lagi 10.000 rpm selama 10 menit. Supernatan dibuang secara perlahan dan pelet dibiarkan pada tabung. Pelet disuspensi dengan PBS steril dan disentrifugasi lagi $12.000 \mathrm{rpm}$ selama 10 menit sebagai langkah pencucian limfosit. Pelet hasil sentrifugasi ini merupakan limfosit yang siap digunakan sesuai keperluan.

\section{Pembuatan Sel Heterohibrida}

Penyiapan sel heterohibrida dilakukan sesuai dengan metode yang dilakukan oleh 
Astawa et al., (2005). Sel mieloma mencit ditumbuhkan pada media DMEM (Dulbeco"s Modified Essential Medium) yang mengandung serum (foetal calf serum/ FCS) 10\%, antibiotik, glutamin dan sodium piruvat. Sebanyak $2 \times 10^{6}$ sel mieloma yang sehat dan sedang aktif membelah, difusikan dengan $10^{8}$ limfosit sapi Bali normal menggunakan larutan PEG (polyethelene glycol) 45\%. Hasil fusi ini dibiakkan pada media selektif DMEM yang mengandung hypoxantine, aminopterin dan thymidin (HAT). Sel yang tumbuh kemudian diidentifikasi, diseleksi, dan diisolasi.

\section{Tahapan Karyotiping}

Uji karyotiping meliputi tahapan berikut sesuai metode Dr. Patricia Labosky's protocol. Sebanyak $20 \mathrm{ml}$ sel heterohibrida dari kultur diambil dan diencerkan sehingga konsentrasinya

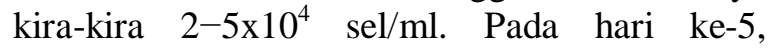
colcemid (Sigma, USA) dengan konsentrasi akhir $10^{-7} \mathrm{M}$ ditambahkan ke dalam medium kultur. Setelah inkubasi 4-6 jam, medium kultur dibuang secara hati-hati dan trypsin $0,25 \%$ sebanyak $5 \mathrm{ml}$ ditambahkan dan inkubasi selama 10 menit. Sel disentrifugasi dan supernatan dibuang. Sel dituangkan dalam $5 \mathrm{ml}$ larutan hipotonik $(0,56 \% \mathrm{KCl})$ dan diinkubasi 20 menit pada suhu $36,5^{\circ} \mathrm{C}$. Acetiat metanol yang didinginkan sebanyak volume yang sama $(5 \mathrm{ml})$ ditambahkan, dicampur merata dan disentrifugasi pada 100 G selama 2 menit. Supernatan dibuang, pelet dicampur menggunakan vortex, secara perlahan acetiat metanol baru ditambahkan dan dicampur merata. Kemudian didiamkan dalam es selama 10 menit, dan disentrifugasi pada $100 \mathrm{~g}$ selama 2 menit. Supernatan acetiat metanol dibuang dan pelet dicampur dengan $0,2 \mathrm{ml}$ acetiat metanol baru sehingga didapatkan konsentrasi akhir, dengan pipet pasteur diteteskan satu tetes sediaan diatas gelas objek dingin Dibiarkan tetesan menyebar di atas gelas objek. Sediaan dikeringkan dengan menaruh gelas objek di atas cawan berisi air panas dan amati dibawah mikroskop. Jika sel menumpuk sehingga sulit untuk diamati, sediaan diencerkan sebanyak 2 atau $4 \mathrm{x}$ dan buat preparat baru. Pewarnaan dengan Giemsa dilakukan dengan cara diteteskan Giemsa dan biarkan selama 2 menit. Bilas pewarna Giemsa dengan air mengalir (perlahan). Bila pewarnaan sudah cukup, ditutup dengan cover slip dan permount. Pemeriksaan di bawah mikroskop dilakukan dengan menghitung jumlah kromosom dan kemungkinan adanya kelainan kromosom.

\section{Hasil dan Pembahasan}

Dalam uji karyotiping, selain dilakukan terhadap sel heterohibrida juga terhadap limfosit sapi Bali dan mieloma mencit sebagai asal dari sel heterohibrida. Hasil uji karyotiping sel heterohibrida dan sel mieloma mencit secara keseluruhan bersifat diploid (Gambar 2). Uji karyotiping terhadap limfosit sapi Bali tidak berhasil dilakukan, sehingga kromosom tidak dapat diamati diploid atau tidak dan juga tidak dapat dihitung. Banyaknya pasangan (2n) dari hasil uji karyotiping sel limfosit sapi Bali, mieloma mencit dan sel heterohibrida (Tabel 1).

Pada uji karyotiping sel limfosit sapi Bali, tidak tampak inti sel membelah untuk menampakkan keadaan kromosom, berarti sel tidak dalam proses mitosis. Keadaan ini berbeda dengan sel mieloma mencit dan sel heterohibrida, di mana kromosom dapat diamati dan dihitung. Hal ini sesuai dengan prinsip uji karyotiping adalah menghentikan pembelahan sel pada tahap metafase pada proses mitosis, di mana pada tahap tersebut kromosom akan tampak memisahkan diri dari pasangannya dan jumlah pasang kromosomnya dapat dihitung (Kiernan, 1990). Hal ini menunjukkan bahwa sel mieloma dan sel heterohibrida berada dalam keadaan mitosis. Keadaan ini dikategorikan sebagai sel yang mengalami instabilitas. Walaupun demikian, sel heterohibrida tidak menunjukkan adanya karakter sel kanker. Sel kanker memiliki karakter kromosom yang aneuploid atau tata letak kromosom yang tidak teratur (Camps et al., 2005).

Secara keseluruhan kromosom sel heterohibrida tampak bersifat berpasangan (diploid) yang menunjukkan bahwa kromosom dalam kondisi normal atau tidak membawa karakter aneuploid sebagai ciri kromosom sel kanker. Kromosom pada sel yang bersifat sel kanker biasanya aneuploid baik pada pemeriksaan hibridisasi genomik maupun karyotiping (Reid, 2000). Sifat ketidakstabilan kromosom berkorelasi dengan aneuploid dan memudahkan sel mengalami mutasi termasuk 
perubahan ke arah sel kanker (Fabarius et al., 2003). Demikian pula poliploid merupakan tanda dari kecepatan sel membelah yang merupakan ciri dari sel kanker (Camps et al., 2005).

Hasil penghitungan jumlah diploid pada sel heterohibrida rata-rata 97 pasang kromosom, padahal diploid normal sapi adalah 60 pasang, menunjukkan adanya peningkatan jumlah kromosom. Hasil ini berbeda dengan laporan penelitian Albert et al., (1994) yang menyatakan bahwa heterokarion sel tikus-manusia, sebagian kromosomnya hilang secara acak, sehingga jumlah kromosom akhir cenderung mengikuti jumlah kromosom spesies yang lebih dominan. Pada heterokarion tikus-manusia akan memiliki sebuah atau beberapa kromosom manusia. Pada penelitian karyotiping sel heterohibrida tampaknya terjadi gabungan kromosom mencit dengan kromosom sapi, sehingga rata-rata kromosom 97 pasang atau mendekati jumlah 100 diploid. Diploid (2n) kromosom mencit adalah 40 (Meng, 2008). Hal tersebut kemungkinan berkaitan dengan belum stabilnya sel karena fusi dua sel dari spesies berbeda dilaporkan bersifat labil atau dapat beragam (Albert et al., 1994). Berkaitan dengan proses mitosis sel secara normal, maka pada tahap metafase akan terjadi pemisahan kromosom dan jelas teramati adanya diploid. Pada tahap metafase inilah yang teramati dalam teknik karyotiping. Jika banyak sel yang bersifat abnormal, tahap metafase tidak secara utuh teramati. Abnormalitas ini kemungkinan disebabkan antara lain oleh faktor ketidakstabilan sel (karsinogenik), dan faktor keturunan (herediter) (Encyclopedia, 2008).

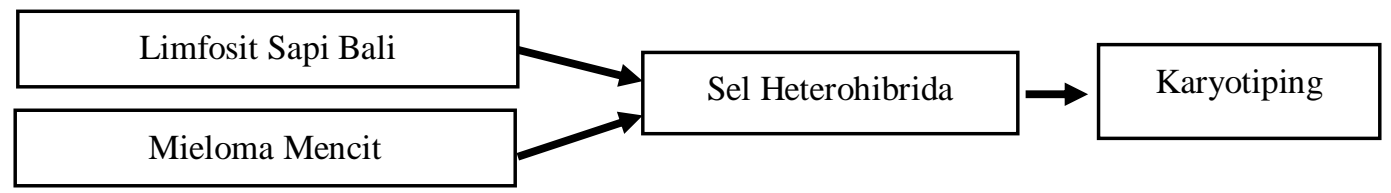

Gambar 1. Alur Kerja Penelitian.

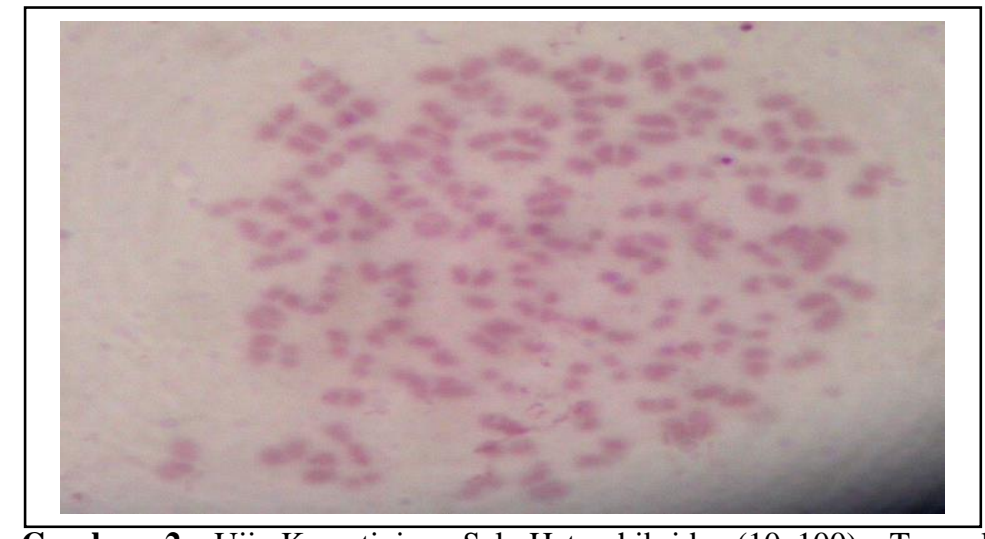

Gambar 2. Uji Karyotiping Sel Heterohibrida (10x100). Tampak kromosom secara keseluruhan berpasang-pasangan (diploid).

Tabel 1. Hasil Penghitungan Jumlah Pasang Kromosom (2n) dari Limfosit Sapi, Mieloma mencit dan Sel Heterohibrida Setelah Uji Karyotiping.

\begin{tabular}{cccc}
\hline \hline Ulangan & Limfosit Sapi Bali & Mieloma Mencit & Sel Heterohibrida \\
\hline \hline 1 & - & 64 & 101 \\
2 & - & 62 & 96 \\
3 & - & 60 & 100 \\
4 & - & 63 & 99 \\
5 & - & 58 & 99 \\
6 & - & 66 & 98 \\
7 & - & 56 & 96 \\
8 & - & 59 & 88 \\
9 & - & 60 & 91 \\
10 & - & 58 & 102 \\
\hline \hline Rerata & - & $\mathbf{6 1}$ & $\mathbf{9 7}$ \\
\hline \hline
\end{tabular}

Keterangan : $(-)=$ kromosom tidak dapat dihitung karena inti sel tidak pecah. 


\section{Simpulan dan Saran}

\section{Simpulan}

Berdasarkan uji karyotiping menunjukkan bahwa sel heterohibrida memiliki karakter diploid, yang menandakan tidak adanya karakter sel kanker. Jumlah kromosom sel heterohibrida rata-rata 97 pasang, yang menunjukkan kemungkinan masih labilnya sel heterohibrida pada tahap yang diteliti.

\section{Saran}

Perlu dilakukan penelitian tentang fasefase kultur sel heterohibrida untuk memperoleh fase stabilnya yang ditandai dengan jumlah kromosom yang mendekati salah satu asal sel (sel limfosit sapi atau mencit).

\section{Ucapan Terima Kasih}

Terima kasih kepada Prof. drh. Nyoman Mantik Astawa, $\mathrm{PhD}$ atas bantuan teknik pembuatan sel heterohibrida dan kepada DP2M Dikti Depdiknas RI atas dana penelitian fundamental, untuk penelitian ini.

\section{Daftar Pustaka}

Albert, B., Brray, D., Lewis, J., Raff, M., Robert, K. dan Watson, J.D. 1994. Molecular Biology of The Cells. Garland Publishing. Inc.1-346.

Astawa, N.M., Hartaningsih, N., Dharma, D.M.N., Tenaya, W.M., Budiantono dan Ekaana, W. 2005. Replikasi Virus Jembrana pada Kultur Limfosit Darah Tepi asal Sapi Bali. J.Vet, 6 (4): 135-142.

Berata, I.K. dan Astawa, I.N.M. 2007. Protein Kapsid Virus Penyakit Jembrana Menginduksi Kekebalan Seluler pada Mencit. J.Vet, 8 (3): 147-154.
Camps, J., Ponsa, I., Ribas, M., Prat, E., Egoscue, J., Peinado, M.A. dan Miro, R. 2005. Coprehensive Measurement of Chromosomal Instability in Cancer Cells: Combination of Flourecence in Situ Hibrydization and Cytokinesis-Block Micronucleus Assay. The FASEB J.Express Article doi: 10.1096/fj.042276fje. 03/03/2009.

Encyclopedia. 2008. Chromosomal abnormalities - Normal Number and Structure of Human Chromosomes, Normal Cells Division, Alteration of Chromosome Structure, Genetic Counseling - Alteration in Chromosome Number. Science Encyclopedia, 2: 1-3.

Fabarius, A., Helhmann, R. dan Duesberg, P.H. 2003. Instabillity of Chromosome Structure in Cancer Cells Increases Exponentiantly with Degree of Aneuploidy. Cancer Genet Cytogenet, 143 (1): 59-72.

Hartaningsih, N., Dharma, D.M.N., Soeharsono, S. dan Wilcox, G.E. 2001. The Induction of Protective Immunity Against Jembrana Disease in Cattle by Vaccination With Inactivated TissueDerived Virus Antigens. Vet. Immunol. and Immunopathol, 78: 163-176.

Kertayadnya, G., Wilcox, G.E., Soeharsono, S., Hartaningsih, N., Coelen, R.J., Cook, R.D., Collins, M.E. dan Brownlie, J. 1993. Characteristics of A Retrovirus Associated With Jembrana Disease in Bali Cattle. J. of. Gen. Virol, 74: 1765-1773.

Kiernan, J.A. 1990. Histological and Histochemical Methods: Theory \& Practice. $2^{\text {nd }}$ Ed. Pergamon Press. 330-354.

Meng, G.Y. 2008. Comparative Anatomy and Phisiology. Workshop on the Care and Use of Laboreatory Animal Research. Collaboration Fac.Vet.Med. Airlangga Univ. and Fac.Vet. Med. Univ. Putra Malaysia.

Reid, T. 2000. Chromosomes in Cancer Cells. Genetics Department, Div.Clinal Science. National Cancer Institute/NIH, Bldg, 9, Rm. 